\title{
LIBERDADE! LIBERDADE! ABRE AS ASAS SOBRE NÓS: "VICENTE", DE MIGUEL TORGA ${ }^{1}$
}

\author{
Lyza Brasil Herranz?
}

RESUMO: Incluído em Bichos, de Miguel Torga, o conto "Vicente", espécie de fábula moderna, narra a escolha humana por uma existência telúrica, ao invés de desenraizada, e pela resistência à opressão ao invés da servidão. Em sintonia com o ensinamento crítico-filosófico de Étienne de La Boétie em seu Discurso da servidão voluntária, o corvo Vicente, protagonista da narrativa, ensina que a vida só tem valor em plena liberdade, conquistada pelo próprio homem.

Palavras-chave: Miguel Torga, Terra, Opressão, Étienne de La Boétie, Liberdade.

\section{FREEDOM! FREEDOM! OPEN THE WINGS ABOVE US: "VICENTE", BY MIGUEL TORGA}

\begin{abstract}
Included in Bichos, by Miguel Torga, the tale "Vicente", kind of a modern fable, narrates the human choice for a telluric existence instead of an uprooted one and for resistance to oppression instead of servitude. According to Étienne de La Boétie's critical-philosophical teaching in his Discourse on voluntary servitude, the raven Vicente, protagonist of this narrative, teaches that life only has value in full freedom, conquered by man himself.
\end{abstract}

Keywords: Miguel Torga, Earth, Oppression, Étienne de La Boétie, Freedom.

Liberdade - essa palavra que o sonho humano alimenta: que não há ninguém que explique, e ninguém que não entenda! Romanceiro da inconfidência, Cecília Meireles

Terra. Quanto a palavra der, e nada mais. "Iberia", Miguel Torga

O modo de pensar a criação artística, sobretudo a literária, sofreu um forte impacto quando, em 1969, Julia Kristeva, articulando um complexo discurso teórico-crítico acerca de leitura e texto, cunhou o termo "intertextualidade" ao dizer que "todo texto se constrói como mosaico de citações, todo texto é absorção e transformação de um outro texto. Em lugar da

\footnotetext{
${ }^{1}$ O título faz referência aos versos do Hino da Proclamação da República do Brasil eternizados por Niltinho Tristeza, Preto Joia, Jurandir e Vicentinho no samba-enredo que levou a Imperatriz Leopoldinense ao título em 1989 e ganhou o Estandarte de Ouro.

${ }^{2}$ Doutoranda em Literatura Brasileira/UFRJ e professora de Português e Literaturas de Língua Portuguesa do Colégio Pedro II.
} 
noção de intersubjetividade, instala-se a de intertextualidade" (KRISTEVA, 1974, p. 64, grifo nosso). A partir desse momento, tornou-se inconcebível a ideia de texto como uma manifestação isolada e independente, já que nenhum texto é escrito sem que a tradição esteja, de antemão, inscrita nele. A maneira pela qual a tradição é retomada é que determina se o intertexto será uma paráfrase ou uma paródia. O conto "Vicente", de Miguel Torga, incluído na coletânea Bichos (1940), dialoga explicitamente com o Gênesis, primeiro livro do Velho Testamento. Autora de "Miguel Torga e a 'recusa do divino", Nayade Anido (1975) considera essa narrativa, dentre as catorze do livro, a mais bela (pela temática e pelo estilo), a mais importante (porque resume toda a ideologia de Torga) e a mais reveladora da atitude do poeta perante o sagrado.

A fabulação inicia com um cenário terrível, “à hora em que o céu se mostrava mais duro e mais sinistro" (TORGA, 1990, p. 127), no qual o corvo Vicente, "figura negra e seca" (TORGA, 1990, p. 127), foge da Arca construída por Noé4. É em relação ao episódio do Dilúvio que o autor estabelecerá sua paródia, no sentido etimológico de "canto paralelo" ressaltado por Haroldo de Campos no estudo das Memórias sentimentais de João Miramar, de Oswald de Andrade ${ }^{5}$, e recuperado por Olga de Sá no ensaio sobre A paixão segundo G.H., de Clarice Lispector ${ }^{6}$. Da mesma forma que Clarice não ridiculariza a Paixão de Cristo em sua obra-prima, mas, de maneira profundamente séria, a subverte em prol de seu próprio itinerário, assim também o faz Torga ao escrever essa narrativa como um contracanto irônico que "desescreve" o que foi escrito pela tradição literária ocidental.

No simbolismo moderno, sobretudo europeu, o corvo é ave agourenta, noturna e mensageira da morte. Nas mitologias grega e chinesa, porém, é animal solar e ordenador, arauto de bons presságios. Segundo Chevalier e Gheerbrant (1988), esse aspecto positivo vincula-se às crenças dos povos nômades, caçadores e pescadores, e torna-se negativo com o desenvolvimento da agricultura e a subsequente sedentarização. Na Bíblia, o corvo é o

\footnotetext{
3 As citações de "Vicente" e outros contos da obra foram retiradas da $18^{a}$ edição de Bichos, Coimbra: Coimbra Editora, 1990.

${ }^{4}$ A Arca de Noé é mencionada pela primeira vez no prefácio da obra, escrito pelo autor - "São horas de te receber no portaló da minha pequena Arca de Noé" (p. 7) -, e depois no penúltimo conto, "O senhor Nicolau": "E foi assim, herdeiro das ricas terras do pai, e com a Arca de Noé sabida de cabo a rabo, que o Sr. Nicolau voltou definitivamente a Pedornelo" (p. 121).

${ }^{5}$ CAMPOS, Haroldo de. "Miramar na mira". Memórias sentimentais de João Miramar. São Paulo: Difusão Europeia do Livro, 1964.

" SÁ, Olga de. "Paródia e metafísica". A paixão segundo G.H. (edição crítica). Paris: Association Archives de la littérature latino-américaine, des Caraibes et africaine du XXe. Siècle; Brasília, DF: CNPq, 1988.
} 
primeiro animal a ser liberado por Noé, mas seu destino é desconhecido, uma vez que, ao contrário da pomba, solta logo em seguida, ele não retorna à arca. Lê-se em Gênesis, 8:6-11:

Ao cabo de quarenta dias, abriu Noé a janela que havia feito na arca; soltou um corvo que, saindo, ia e voltava até que as águas secaram de sobre a terra.

Depois soltou uma pomba, para ver se as águas tinham minguado de sobre a face da terra; mas a pomba não achou onde pousar a planta do pé, e voltou a ele para a arca; porque as águas ainda estavam sobre a face da terra; e Noé, estendendo a mão, tornou-a e a recolheu consigo na arca. Esperou ainda outros sete dias, e tornou a soltar a pomba fora da arca. À tardinha a pomba voltou para ele, e eis no seu bico uma folha verde de oliveira; assim soube Noé que as águas tinham minguado de sobre a terra. (BÍBLIA, 2002, p. 7)

$\mathrm{Na}$ narrativa torguiana, o destino do corvo será forjado como consequência de um ato único e voluntário: abrir as asas e partir. Vicente fora um dos "escolhidos" e, resignado, entrara na Arca; porém, “desde o primeiro instante que todos viram que no seu espírito não havia paz. Calado e carrancudo, andava de cá para lá numa agitação contínua, como se aquele grande navio onde o Senhor guardara a vida fosse um ultraje à criação" (TORGA, 1990, p. 127). A atitude inconformada de Vicente lembra, segundo Étienne de La Boétie no seu Discurso da servidão voluntária, a de alguns animais que, quando são capturados,

opõem viva resistência com unhas, chifres, bico e pés para manifestar o valor que dão ao que perdem. E, quando estão presos, dão tantos sinais evidentes do conhecimento que têm de sua desgraça que é possível ver claramente que, daquele momento em diante, eles se debilitam em vez de viver, e continuam a viver mais para lamentar seu bem-estar perdido que para se comprazer na servidão. (BOÉTIE, 2017, p. 32-33)

Em sua obra, o filósofo francês defende que os povos se deixam maltratar quando renunciam à liberdade e aceitam o jugo e que, portanto, a tirania se destrói sozinha quando os indivíduos se recusam a consentir com a própria escravidão. Para ele, os homens devem aprender com os animais a verdadeira natureza e condição humana: "Os animais, valha-me Deus, se os homens quiserem ouvi-los, lhes gritam: 'Viva a liberdade!” (BOÉTIE, 2017, p. 32).

Se no texto matriz, a arca é um espaço de salvação, criado por Noé para resguardar a vida e protegê-la da ira divina, no conto ela se converte em prisão para os "eleitos", que, embora desprovidos de toda a coragem e a ousadia do companheiro, sentem-se igualmente 
condenados e recebem “das mãos servis de Noé a ração quotidiana” (TORGA, 1990, p. 128). Para Vicente, os seres da Arca, desde o início reduzidos "a uma pura passividade vegetativa" (TORGA, 1990, p. 129), haviam abdicado de sua energia vital sem um motivo que justificasse a situação humilhante: "a que propósito estavam os animais metidos na confusa questão da torre de Babel? Que tinham que ver os bichos com as fornicações dos homens, que o Criador queria punir?” (TORGA, 1990, p. 127-128). A revolta, repulsa e indignação do corvo, cada vez maiores, levam-no a superar o "instinto da própria conservação” (TORGA, 1990, p. 128) e abandonar a Arca em direção à “imensidão terrível do mar” (TORGA, 1990, p. 128). Igualmente terrível é a voz de Deus, "larga como um trovão, penetrante como um raio" (TORGA, 1990, 128-129), que imediatamente questiona Noé sobre o paradeiro de Vicente, deixando todos, sobretudo o Patriarca bíblico, petrificados de medo. É nesse instante que Torga inicia a desmontagem da figura hierática de Noé, que remonta à epopeia mais antiga do mundo: a epopeia de Gilgamesh.

A versão assíria, utilizada como texto padrão para os editores modernos, teria sido obra de Sinleque'unneni, composta em princípios do primeiro milênio antes de Cristo num antigo dialeto acadiano, língua semita. Da versão babilônica antiga, há um conjunto menor de textos, em sua maioria fragmentários, escritos entre 1750 e 1700 a.C. A epopeia tem por base sagas sumérias do ciclo de Gilgamesh, herói semidivino, que remontam ao período de 2150 a 2000 a.C., época do Renascimento Sumério. Ordep Serra afirma que “outros relatos míticos poetizados em Súmer também foram aproveitados, em parte, na composição da epopeia, como é o caso do Poema do Dilívio" (SERRA, 1985, p. 5).

Figura histórica que se tornou lendária, Gilgamesh consta na antiga lista dos reis sumérios como o quinto rei de Uruk (ou Erech, nos textos bíblicos), cidade mesopotâmia fundada pelos sumérios no sul do Iraque, país cujo nome parece derivar desse topônimo. A antiquíssima urbe teve seu apogeu por volta do ano de 2900 a.C, quando era então a maior cidade do mundo.

$\mathrm{Na}$ trama da narrativa épica, a busca desesperada pela imortalidade, após a perda do amigo Enkidur, leva Gilgamesh a uma viagem aos confins da terra, onde ele encontra, por fim, a trilha que o conduz a Utnapishtim, o Noé acadiano, que, em Súmer, tinha o nome de Ziusudra. Questionado sobre a sua imortalidade, o longínquo sobrevivente, obrigado pelos deuses a viver no mais remoto dos sítios, conta ao herói o episódio do "horrendo dilúvio" 
para mostrar as circunstâncias e o privilégio extraordinários de sua situação, impossível de se repetir:

\begin{abstract}
conta-lhe, então, como os deuses, outrora, decidiram submergir a terra no horrendo dilúvio e como seu protetor, o sábio Ea, por meio de um ardil, avisou-o deste desígnio divino, ordenando-lhe a construção de um barco gigantesco no qual deveria reunir "as sementes de todas as coisas vivas". Relata a faina da construção e as equívocas respostas que, instruído por Ea, dava à curiosidade do povo; narra como, depois do prazo que o deus lhe concedera, teve início a calamidade, com o vendaval furioso arrasando a terra por sete dias e sete noites.

"A ampla terra foi partida como um pote!"

Mesmo os deuses, filhos de Anu, apavorados e humildes, encolheram-se como cães junto aos muros dos céus; já os homens tinham todos retornado ao barro. Com a cessação das chuvas, o barco estacou junto ao monte Nisir. Depois de assegurar-se da estiagem despachando pássaros sucessivamente, Utnapishtim desceu e fez um sacrifício. Os deuses acorreram aspirando o perfume das libações; por último veio Enlil, que determinara o dilúvio. Este deus, a princípio, ficou indignado, "porque escapou alma viva"; contudo, aplacado por Ea, resolveu, depois, favorecer Utnapishtin e sua mulher com o dom da vida eterna, levando-os a habitar "bem longe, na foz dos rios". (SERRA, 1985, p. 19)
\end{abstract}

Se na epopeia, como na Bíblia, o Patriarca inspira respeito, no conto de Torga, ele é um homem fraco e amedrontado, que logo tenta enganar o Senhor - assim Noé se refere a Deus, reforçando a autoridade e a prepotência deste, que faz dos outros os seus servos - ao fingir que Vicente ainda estava na Arca. Mas alguém", "compadecido da mísera pequenez daquela natureza, pôs fim à comédia” (TORGA, 1990, p. 129). Desgraçado, Noé desmaia: "De repente, bambearam-lhe as pernas e caiu redondo no chão. (...) Acordado do desmaio poltrão, trémulo e confuso" (TORGA, 1990, p. 129-130), tenta defender-se e justificar-se, sem sucesso: "ouvia-se, infantil, o choro desesperado do Patriarca, que tinha então seiscentos anos de idade" (TORGA, 1990, p. 130). O contraste entre o choro infantil e a idade longeva confirma a redução irônica a que o escritor submete o modelo original. À fraqueza moral do homem (a mentira) junta-se a fraqueza física do velho (o desmaio), completando o desenho grotesco de um personagem medroso e covarde, ao qual se adequa perfeitamente a imagem do poltrão infantilizado que o exclui da natureza típica do herói épico.

Revelada a fuga de Vicente, a Arca, "que até ali vogara indecisa e morosa ao sabor das ondas" (TORGA, 1990, p. 131), parte ao encontro da ovelha desgarrada: "E a seguir,

\footnotetext{
${ }^{7}$ A palavra reforça o caráter de fábula da narrativa ao humanizar o animal que fez a intervenção.
} 
como que guiada por um piloto encoberto, como que movida por uma força misteriosa, apressada e firme (...) dirigiu-se para o sítio onde quarenta dias antes eram os montes da Armênia” (TORGA, 1990, p. 131). Nesse lugar, Noé e os outros bichos, testemunhas silenciosas da partida de Vicente, o veem literalmente agarrado ao seu "telúrico destino" (p. 133).

O destino de Vicente está ligado à terra como o filho à mãe pelo cordão umbilical. $\mathrm{O}$ "ventre quente da mãe" (TORGA, 1990, p. 132) - contraposto ao abismo gélido do pai remete ao mito de Gaia, nome dado pelos gregos à Mãe Terra. Na Teogonia, de Hesíodo, ela é uma das divindades primordiais, nascida logo após Caos. Com sua infinita potência progenitora, Terra pariu igual a si mesma o constelado Céu, para que a cobrisse inteira. Fecundada por ele, deu à luz divindades cósmicas, como Memória, mãe das Musas, que inicialmente eram um trio venerado no santuário do monte Hélicon: "Pelas Musas heliconíades comecemos a cantar./ Elas têm grande e divino o monte Hélicon” (HESÍODO, 2011, p. 103). Segundo Heide Göttner-Abendroth (1991), este esquema triádico corresponde à natureza unitrina da musa primordial do canto e da dança, que institui as três regiões do ordenamento cósmico: o superno, região na qual habitam as constelações divinas; o inferno, região subterrânea onde se originam os misteriosos poderes da morte e da ressurreição; e a região mediana do mundo humano composta por terra e mar.

Em "Vicente", Torga retorna a essa região primeva, essencialmente reduzida a dois espaços - terra e mar - para inverter os valores que eles adquiriram na tradição literária ocidental inaugurada pelo texto bíblico. Na recriação do mundo, o autor recusa o primeiro como lugar de perdição, punição e morte porque o que nasce do ventre fértil da terra é a própria vida. Na sua obra, ela é cantada em prosa e em verso, como no poema "A Terra": “Terra, minha aliada/ Na criação! (...) Terra, minha canção!/ Ode de polo a polo erguida/ Pela beleza que não sabe a pão/ Mas ao gosto da vida!” (TORGA, 2014, p. 314). Protetora e generosa, nela repousa a grandeza do mundo e do homem, que se alimenta de sua seiva e, no seu ciclo vital, a tem como princípio e fim de sua existência mortal.

Terra! Nem planaltos, nem veigas, nem desertos. Nem mesmo a maciez tranquilizadora dum monte. Apenas a crista de um cerro a emergir das vagas. Mas bastava. Para quantos o viam, o pequeno penhasco resumia a grandeza do mundo. Encarnava a própria realidade deles, até ali transfigurados em meros fantasmas flutuantes. Terra! Uma minúscula ilha de solidez no meio dum abismo movediço, e nada mais importava e tinha sentido. (TORGA, 1990, p. 132) 
No ensaio "Ao princípio era a terra: a (des?)propósito do teatro de Torga”, Teresa Rita Lopes escreve: "Dir-se-ia que Torga tenta, na sua obra, recuperar homens e coisas por um batismo de terra. Recuperar?... Sim, da degeneração de existirem domesticados, que o mesmo é dizer desenraizados. Recuperar, que o mesmo é dizer curar” (LOPES, 1978, p. 53). No Díario IX, Torga declara: "O meu segredo é este: curo as chagas com pensos de terra" (TORGA, 1964, p. 47). Amante da terra, principalmente de sua terra natal, Trás-os-Montes, seu sobrenome artístico é uma homenagem à planta que nasce selvagemente nas montanhas nortistas. A relação concreta que liga o homem à terra como o modo de sua existência e de seu destino, o afeto que a transforma em lugar, enfim, a geograficidade a que se refere Eric Dardel (2015), Torga a carrega no próprio nome.

Desse modo, o duelo entre o corvo e Deus acaba por ser espacial na medida em que a disputa pela porção mínima de terra que o Senhor deseja submergir junto com Vicente, o legítimo fruto do seio materno, simboliza a retomada da terra - palavra repetida seis vezes, cinco sob forma exclamativa -, como lugar vital e não mortal. Essa reivindicação está ainda em outros contos de Bichos, como é o caso de "Ladino": "Terra! Pisava-a pela primeira vez! Qualquer coisa de mais áspero do que o veludo do ninho, mas também quente e segura" (TORGA, 1990, p. 93); e de "Bambo", no qual o sapo inicia o homem no mistério maior do amor telúrico:

Seduzida e contagiada, a alma do trabalhador abria-se pouco a pouco às íntimas razões dessa comunhão profunda. Ao lado da sua serenidade e do seu apego à terra, do que nela havia de essencial - o dom de fecundar e parir -, ia conseguindo auscultar as imponderáveis palpitações da seiva. (TORGA, 1990, p. 66)

Em "Vicente", a morte está no canto da sereia, está na desmesura aquática e estéril: "Contra o homem, acima do homem, força hostil e superior, o mar em fúria faz às vezes pensar que uma potência sem alma surge das entranhas do mundo" (DARDEL, 2015, p. 21). $\mathrm{Na}$ conhecida dicotomia Céu-Terra, o primeiro termo, “mística mansão/ Da alma”, oposto ao segundo, "sórdida morada/ Da raiz", pode ser substituído, na obra torguiana, pelo Mar. As primeiras peças publicadas em 1941, Mar e Terra firme, significativamente no mesmo

\footnotetext{
${ }^{8}$ Nesses versos de "Querem o céu", Teresa Rita Lopes observa que o adjetivo "sórdido" possui uma carga positiva, e "mística", negativa; a oposição entre morada e mansão também é fundamental: "a primeira é coisa simples, ao alcance do bicho-homem, a segunda está para além da sua dimensão" (LOPES, 1978, p. 54).
} 
volume, são um flagrante exemplo disso: “A oposição barco-raiz é obsessiva nessa peça como, aliás, na obra do autor: 'Mas metido num barco, de mar em mar, hoje aqui, amanhã no inferno, - é mundo?, é vida?"' (LOPES, 1978, p. 58). No conto em questão, estão ambos, Céu e Mar, reunidos e vinculados à ação destruidora e violenta de um Deus punitivo e autoritário, como no Velho Testamento.

No momento em que "aquela fauna desiludida e humilhada" (TORGA, 1990, p. 131) descobre o corvo pousado em cima do monte, sente-se imediatamente vingada e, ao mesmo tempo, desesperada "diante daquele submergir irremediável do último reduto da existência activa. Não, ninguém podia lutar contra a determinação de Deus. Era impossível resistir ao ímpeto dos elementos, comandados pela sua implacável tirania” (TORGA, 1990, p. 133). Adeptos distanciados da rebeldia de Vicente, os habitantes da Arca não conseguem transformar o ato subversivo em um projeto revolucionário; eles se limitam a desejar que a força do insubordinado consiga vencer o poder até então invencível da divindade: “A cada vaga, o coração frágil da Arca, dependente do coração resoluto de Vicente, estremeceu de terror” (TORGA, 1990, p. 143). Na elucidação crítico-filosófica de Étienne de La Boétie:

Para conseguir o bem que deseja, o homem ousado não teme nenhum perigo, o homem prudente não regateia nenhum esforço. Só os covardes e os preguiçosos não sabem suportar o mal nem recuperar o bem. Limitam-se a desejá-lo e a energia de sua pretensão lhes é tirada por sua própria covardia. Não lhes resta senão o desejo natural de possuí-lo. Esse desejo, essa vontade comum aos sábios e aos imprudentes, aos corajosos e aos covardes, fez que desejassem todas as coisas cuja posse os tornaria felizes e contentes. (BOÉTIE, 2017, p. 29)

Assim, Vicente resistia: "negro, sereno, único representante do que era raiz plantada no justo meio, impávido (...). Escolhera a liberdade, e aceitara desde esse momento todas as consequências da opção. Olhava a barca, sim, mas para encarar de frente a degradação que recusara" (TORGA, 1990, p. 133). Com firmeza de "raiz", prefigurada nas garras com que se agarra à terra, verdadeiro refúgio, em busca de auxílio e sobrevivência, e ainda com a obstinação de quem luta pelo "justo” meio, o corvo, cujo negror é já a marca do protesto e do luto por uma existência desenraizada e submissa, mantém-se firme e forte em sua decisão: "Eu é que fiz o acto/ De namorar o chão em vez do céu" (TORGA, 2014, p. 146), são versos do poema "Viriato". Esse ato original instaura uma aporia com a qual Deus precisará 
confrontar-se, já que a morte de Vicente põe em xeque o livre arbítrio da criatura e mesmo a sobrevivência da criação:

E no espírito claro ou brumoso de cada um, este dilema, apenas: ou se salvava o pedestal que sustinha Vicente, e o Senhor preservava a grandeza do instante genesíaco - a total autonomia da criatura em relação ao criador -, ou, submerso o ponto de apoio, morria Vicente, e o seu aniquilamento invalidava essa hora suprema. A significação da vida ligara-se indissoluvelmente ao acto de insubordinação. Porque ninguém mais dentro da Arca se sentia vivo. (TORGA, 1990, p. 133-134)

Quando uma onda bem alta ${ }^{9}$, instigada pela mão invisível de Deus, tenta três vezes, número divino por excelência, arrancar Vicente do monte, ele retira da terra, como o herói mítico Anteu, a força necessária para não sucumbir: "Sangue, respiração, seiva de seiva, era aquele corvo negro, molhado da cabeça aos pés, que, calma e obstinadamente, pousado na derradeira possibilidade de sobrevivência natural, desafiava a omnipotência" (TORGA, 1990, p. 134). Há durante toda a narrativa uma luta constante e renhida entre uma força vinda de cima para baixo - a de Deus - e outra de baixo para cima - a de Vicente. À medida que o conto se desenrola, o poder divino progressivamente se enfraquece, perde intensidade, importância, até finalmente ceder sob o peso do adversário: "em breve se tornou evidente que o Senhor ia ceder. Que nada podia contra aquela vontade inabalável de ser livre" (TORGA, 1990, p. 134).

A vitória de Vicente estava decretada desde o título, importante índice narrativo. Vicente é aquele que vence, que conquista; nesse caso, não apenas a sua liberdade, mas a de toda a humanidade: "seu gesto foi naquele momento o símbolo da universal libertação" (TORGA, 1990, p. 128). Vicente é evidentemente um nome humano porque, nessa espécie de fábula moderna, o corvo representa o homem que se rebela contra a opressão: “É a liberdade bem tão grande e tão agradável que, quando se perde, todos os males sobrevêm, e sem ela todos os outros bens, corrompidos pela servidão, perdem inteiramente o gosto e o sabor" (BOÉTIE, 2017, p. 29). O conto encerra o volume, portanto, de forma estratégica: é o (necessário) grito de libertação que ecoa ao final de Bichos, obra lançada sob o céu mais duro e mais sinistro do regime salazarista. Se, como explica Octavio Paz, "a liberdade não é uma filosofia e nem sequer uma ideia: é um movimento de consciência que nos leva, em certos momentos, a pronunciar dois monossílabos: sim e não" (PAZ, 2004, p. 271-272), o grito de

\footnotetext{
${ }^{9}$ Repare-se na oposição implícita entre a altura da onda e a fundura das garras.
} 
Vicente é o "não" que os outros animais, os do conto em particular e os da coletânea em geral, não têm coragem de dizer: "O não inconformado que se diz/ A Deus, à tirania, à eternidade. (...) Temos nas nossas mãos/ O terrível poder de recusar!” (TORGA, 2014, p. 204), canta o poeta em "A flor da liberdade".

Até a sétima edição do livro, lia-se ao final "vontade inabalável de viver" ao invés de "vontade inabalável de ser livre". A substituição, que só foi feita quando a primavera marcelista apontou para um rumo supostamente mais libertário - opositor declarado de Salazar, Torga foi um dos artistas mais vigiados e censurados durante o Estado Novo -, mostrava que, para ele, viver não bastava; a dignidade humana obrigava a que a vida só valesse a pena em plena liberdade, conquistada pelo próprio homem, pois afinal "não só nascemos com ela, mas também com a paixão para defendê-la" (BOÉTIE, 2017, p. 32), como se lê no poema-oração "Liberdade", de Torga:

— Liberdade que está no céu...

Rezava o padre nosso que sabia, A pedir-te humildemente,

O pão de cada dia.

Mas a tua bondade omnipotente

Nem me ouvia.

— Liberdade que estais na terra...

E a minha voz crescia de emoção.

Mas um silêncio triste sepultava

A fé que ressumava

Da oração.

- Até que um dia, corajosamente,

Olhei noutro sentido e pude, deslumbrado,

Saborear, enfim,

O pão da minha fome.

Liberdade, que estais em mim,

Santificado seja o vosso nome. (TORGA, 2014, p. 427)

Subvertendo a oração principal do catolicismo, Torga reza à Liberdade em lugar do Pai Nosso, procurando-a primeiro no céu - mas a bondade onipotente é indiferente à sua prece -, depois na terra - mas um silêncio triste lhe sepulta a fé - até encontrá-la por fim dentro de si mesmo, após corajosamente olhar "noutro sentido", no avesso do homem, onde se engendram, quase ao mesmo tempo, a fome e o pão que a sacia. A liberdade, pois, não está no céu, contra o qual o homem se insurgirá na afirmação de sua liberdade, nem na terra, embora esta seja sua aliada no processo. Afinal, sem a rocha sobre a qual Vicente se apoia, 
todo o projeto falharia e não se concretizaria o ato verdadeiramente genesíaco de emancipação do humano frente ao divino. Mais do que isso:

A rocha resiste à tempestade e à erosão continental; ela e inquebrantável, inalterável, como a base mesma do mundo. "Aqui", declara Goethe, "tu repousas imediatamente sobre uma base que alcança as profundas regiões da terra (...). Nesse momento, as forças íntimas da Terra agem sobre mim". Ele sente a rocha como uma potência que "dá a solidez" à sua alma. (DARDEL, 2015, p. 16)

A "moral da fábula" torguiana ensina que a liberdade só se alcança na intimidade com uma geografia mítica em que se reconhece a Terra como origem e fonte incessante da vida. Para tanto, é preciso destruir o mito do homem, através do qual o ser humano sujeita seres e coisas à sua imagem e semelhança. A mensagem de Torga, traduzida nas palavras de Dardel, é esta: "Vir ao mundo é se destacar da terra, mas sem romper jamais, inteiramente, o cordão umbilical pelo qual a terra nutre o homem. (...) Visto que a terra é a mãe de tudo o que vive, de tudo que é, um laço de parentesco une o homem a tudo que o cerca, às árvores, aos animais, até às pedras" (DARDEL, 2015, p. 48). Nesse sentido, a conquista de Vicente é o que torna o homem humano (mas não demasiadamente humano) para que ele possa, assim, assumir a construção de seu próprio projeto de vida.

\section{REFERÊNCIAS BIBLIOGRÁFICAS}

ANIDO, Nayade. Miguel Torga e a "recusa do Divino". Revista Colóquio/Letras, Lisboa, n. 24, p. 31-40, 1975.

A BÍBLIA SAGRAD A: Velho Testamento e Novo Testamento. São Paulo: Hagnos; Rio de Janeiro: JUERP, 2002.

BOÉTIE, Étienne de La. Discurso da servidão voluntária. São Paulo: Martin Claret, 2017.

CHEVALIER, Jean; GHEERBRANT, Alain. Dicionário de simbolos: mitos, sonhos, costumes, gestos, formas, figuras, cores, números. Rio de Janeiro: José Olympio, 1988.

DARDEL, Eric. O homem e a terra: natureza da realidade geográfica. São Paulo: Perspectiva, 2015.

GÖTTNER-ABENDROTH, Heide. The Dancing Goddess. Boston: Beacon Press, 1991.

HESÍODO. Teogonia. São Paulo: Iluminuras, 2011.

KRISTEVA, Julia. Introdução à semanálise. São Paulo: Perspectiva, 1974. 
LOPES, Teresa Rita. Ao princípio era a terra: a (des?)propósito do teatro de Torga. Revista Colóquio/Letras, Lisboa, n. 43, p. 51-61, 1978.

PAZ, Octavio. O humano e a miséria estética. In: BOMBASSARO, Luiz Carlos; PAVIANI, Jayme. As fontes do humanismo latino: o sentido do humano na cultura brasileira e latinoamericana. Porto Alegre: EDIPUCRS, 2004.

SERRA, Ordep. A mais antiga epopeia de mundo: a gesta de Gilgamesh. Salvador: Fundação Cultural, 1985.

TORGA, Miguel. Bichos. Coimbra: Coimbra Editora, 1990. Diário IX. Coimbra: Coimbra Editora, 1964. - Antologia poética. Alfragide: D. Quixote, 2014. 